\title{
Fermitin Family Homolog 3
}

National Cancer Institute

\section{Source}

National Cancer Institute. Fermitin Family Homolog 3. NCI Thesaurus. Code C117080.

Fermitin family homolog 3 ( $667 \mathrm{aa}, \sim 76 \mathrm{kDa}$ ) is encoded by the human FERMT3 gene.

This protein plays a role in hematopoietic cell adhesion, migration and proliferation. 